\title{
Employment Status of Criminology Graduates
}

\author{
Dana Febra A. Ruiz ${ }^{1}$ \\ Paulino V. Pioquinto ${ }^{2}$ \\ Mauro Allan P. Amparado ${ }^{3}$ \\ University of Cebu Lapu-Lapu and Mandaue (UCLM), \\ Mandaue City, Cebu, Philippines \\ mapamparado@gmail.com
}

1. Faculty, College of Criminology

2. Dean, UCLM College of Criminology

3. Director, UCLM Alumni Association

\begin{abstract}
The study determined the employment status of the Criminology graduates of UCLM, Mandaue City, Cebu, Philippines. The study utilized the descriptive method using a researchermade survey questionnaire. The respondents of this study were the criminology graduates of UCLM from 2007-2012. This study was conducted in 2014.

The study revealed that most of the respondents were employed, holding a regular or permanent position. There are graduates who are working in private sectors. Some were employed less than a year after graduating and most of their jobs are relevant to the program. For those unemployed, graduates claimed that they had health reasons or family concerns. They tried to join the law enforcement but failed. On employability skills, majority are efficient on disassembling and assembling firearms and knowledgeable on collecting, preservation and handling of evidence. Graduates were weak in formulating questions in relation to investigation. On interpersonal skills, most said that they are flexible and can adapt successfully to changing situations and environment.
\end{abstract}

Keywords: Employment status, Criminology graduates, family concerns, Cebu, Philippines

\section{Introduction}

To a student in the beginning years of his studies, a criminology graduate has more chances of getting employed. A criminology graduate may become a police officer or assigned as jail officer, port police personnel, firefighter, and drug enforcement agent. Others may work as hotel and resort in-house security, security officer in department stores, security consultant, civilian investigators, local traffic enforcer and criminology instructor. Despite all these possibilities, there are criminology graduates who may have jobs not related to their chosen course which have molded, prepared, and enhanced their ability. 
Every year, thousands of criminology graduates all over the Philippines try their best effort to attend classes to make sure that they will be able to pass the Criminology Licensure Examination and become licensed criminologists. The eligibility needed for a criminologist to be qualified for a law enforcement job like the Bureau of Jail Management and Penology (BJMP), Bureau of Fire Protection (BFP) and more particularly in the Philippine National Police (PNP), makes success a hindrance.

In the field of criminology, however, graduates may encounter difficulty to be hired in the PNP, which is under the administrative control of the National Police Commission (NAPOLCOM) because of the stringent provisions under Title IV-B (Qualifications Upgrading), Section 14, of the Republic Act (RA) 8551, which amended section 30 of Republic Act 6975. The general qualifications for appointment specify possession of minimum qualification which include citizenship, physical test, formal baccalaureate degree, and eligibility set by the commission; have never been dishonorably discharged from military employment; never been convicted of an offense or crime involving moral turpitude, as well as age, height and weight requirements. All these may also contribute as factors which may hinder a criminologist from becoming members of law enforcement agencies.

\section{Theoretical Framework}

This study is anchored on John Holland's Career Choice Theory which states that when a person chooses a career, he/she would look for jobs where they find people with the same or common interests. They seek environment where they can show off their best assets, their abilities and skills, and be the best person they can be. Holland's theory has identified six (6) personality types: realistic, investigative, artistic, social, enterprising and conventional. It is said that people may fit to one of these types (Marini, 2009).

John Hollands' career choice theory suggests that vocational choice can be predicted and understood by characterizing the personality types of people and modeling the environments in which they live, and then pairing the respective personality types and environment. In short, this means people are attracted to occupations that provide satisfaction and meet their personal needs, but through the interaction of personality types and model environments.

A realistic type of person prefers activities where he is certain of what is real and possible in a given situation and whenever problems arises, this type is capable of dealing with the problem in a practical and effective way. On the other hand, this type may not like therapeutic activities and education. The investigative type prefers activities which utilizes observation, creative investigation on physical, cultural phenomena and biological in order to understand and control such phenomena. Artistic has preference for activities that entail the manipulation of physical, verbal, or human materials to create art forms or products, and to an aversion to explicit, systematic and ordered activities. Social has preference for activities that entail the manipulation of others to inform, train, develop, cure, or enlighten and an aversion to explicit, ordered, systematic activities involving materials, tools or machines. Enterprising has preference for 
activities that entail the manipulation of other to attain organizational goals or economic, and an aversion to observational, symbolic and systematic activities. And conventional has preference for activities that entail the explicit, ordered, or systematic manipulation of data, such as keeping records, filling materials, reproducing materials, organizing written and numerical data according to a prescribed plan, operating business machines and data processing machines to attain organizational or economic goals, and an aversion to ambiguous, free, exploratory or unsystematized activities (Brown \& Lent, 2005).

Thus, career choice is a process that is influenced by on-going experiences of learning. considered a continuous process influenced by on-going learning experiences. It further suggest the use of a natural ability in order to do or learn something (Capuzzi \& Stauffer, 2012).

According to Robinsons (2000), employability skills are those basic requirements necessary for getting, keeping and doing well on a job. These are skills, attitudes and actions that enable workers to get along with their fellow workers and supervisors and to make sound, critical decision. To better prepare students for their future employment, discovering and developing their skills while still in the undergraduate years should be considered, the technical skills, interpersonal skills and conceptual skills are often deemed important.

First-line managers, as well as many middle managers, are heavily involved in technical aspects of the organization's operations. Technical skills include knowledge of and proficiency in a certain specialized field, such as engineering, computers, finance, or manufacturing. For example, an accounts payable manager must be proficient in accounting rules and standardized forms so that she can resolve problems and answer questions that her account payable clerks might encounter. Katz proposed that technical skills become less important as a manager moves into higher levels of management, but even top managers need some proficiency in the organization's specialty (Robbins \& Coulter, 2001).

Hayes defined interpersonal skills as a goal-directed behavior used in face-to-face interactions in order to bring about desired state of affairs. Interpersonal competence depends on the ability to understand and manage dynamics of social interaction. People require both diagnostic and action skills. They need to be able to read behavior and act in ways that will bring about desired actions (2002).

The ability to work well with other people both individually and in a group is a human skill. Because managers deal directly with people, this skill is crucial. In fact, Katz said that human skills remained just as important at the top levels of management as they did at the lowest levels. Managers with good human skills are able to get the best out of their people. They know how to communicate, motivate, lead, and inspire enthusiasm and trust.

Managers must have the ability to think and to conceptualize about abstract situations. They must be able to see the organization as a whole and the relationships among its various subunits and to visualize how the organization fits into its broader environment. These abilities are 
essential to effective decision making, and all managers are involved in making decisions. Conceptual skills are needed by all managers at all levels, but Katz proposed that these skills become more important as they move into top management positions (Robbins \& Coulter, 2001).

Employability plays an important role in the implementation of the departments' learning and teaching strategies. It is part of good learning practice. Students who engage in developing their employability are likely to be independent, reflective and responsible learners.

Innovative learning, teaching and assessment methods which promote student's understanding and help them to engage in 'deep' learning will also enhance their employability. And involving employers in the education experience, for example, through placements, case studies, delivery of guest lectures, can help students appreciate the relevance of their course and learn how to apply theory and knowledge in practical ways in the workplace. In some subject areas, employability links to requirements for accreditation from professional bodies (www.employability.ed.ac.uk).

Police work is without question an intricate undertaking. Current demands and the consequences of responding to them in new and innovative ways intensify the critical role played by the police in American society. It involves the use of an enormous amount of discretion and the use of criminal and civil law and the needs of citizens to sort out myriads of problems (More $\&$ Miller, 2011).

Criminology is the body of knowledge regarding crime as a social phenomenon. It includes within its scope the process of making laws, of breaking laws, and of reacting towards the breaking of laws. The objective of criminology is the development of body of general and verified principles and of other types of knowledge regarding the process of law, crime and treatment or prevention (Adler et. al, 2009). If criminology includes the study of law making, law breaking and the response to law breaking then the role of criminologist is to study these areas (Vilo et. al. 2011).

According to Edwin Sutherland, the definition suggests that the field of criminology is narrowly focused on crime yet broad in scope. By stating, that the objective of criminology is "development of a body of general and verified principles," Sutherland mandates that criminologist, like all other scientists, collect information for study and analysis in accordance with the research methods of modern science (Adler, 2010).

Mendez (2012) cited Escudero stating in an article of the Philippine Star, "the government needs to institute a redirection of skills development program for its college students to address rising employment". This prompted the filling of a bill (Senate Bill No. 2091) titled "The National Career Assessment Examination Act (NCAE). Its aim is to institutionalize a mechanism for providing a redirection of skills and development program by way of harmonizing and matching the supply of post secondary Graduates with the demand of the country's job market (Licudine, 2012). 
In an article of the Philippine Star (May 2013), at least 18 percent of unemployed in the country today are college graduates, according to the National Statistics Office (NSO). The NSO has reported that in January 2013 alone, 608,000 people were added to the labor force. However, the number of employed increased only by 606,000 , meaning another 2,000 were added to the ranks of the unemployed. Furthermore, in a forum organized by the Ayala Foundations Inc., the Socio-economic Planning Secretary said, the figures point to a disturbing high rate of unemployment among college graduates (The Philippine Star, 2013).

The rate of unemployment is very high among college graduates, which partly reflects a mismatch between what is produced by schools and what is required by the market. This also shows that there is insufficient conversation between the schools and the firms.

According to Licudine et. al, (2012), there is a general belief that citizens are the most essential of every nation in the world. This is because the success of the country in terms of economic stability and progress is highly dependent of a nation is one of the products of having educated citizens. The more and the better educated people are the greater the chances of economic development. The government is fully aware of this fact, which is why one of the basic thrust of every country is to provide quality education to its citizens. Education is the key towards progress as it hastens power to liberate citizens from the grips of illiteracy, ignorance and poverty. The Philippines being one of the underdeveloped countries in Asia, is aware that it is also the best escape route from poverty.

A philosophy of a module for tertiary education and national development that the Commission on Higher Education or, the current state of higher education in the Philippines, says that "the environment of freedom, excellence and relevance on higher education harnesses, develops and catalyzes the constructive and productive use of the full potentials potentials of Filipino men and women into becoming a creative, decisive, competitive, critically thinking and acting individuals who will contribute to the attainment of political maturity, economic stability and equitable social progress of the nation" (Module 6, 2013).

In another article of the Philippine Star (2013), it was mentioned that attaining a high percentage in the licensure exam is unquestionably commendable, but for Malayan College Laguna (MCL), an ever more important basis for the success of its graduates is their ability to apply their skills and knowledge in the working world.

Furthermore, MCL's vice president for academic affairs, admitted that scoring a high a passing rate in board exams does make a strong impression. It creates a very strong impression especially in terms of quality of education but at the end of the day, it all boils down to the question.

The measure of a university or college's success is the employability of their graduates. It is highly appreciated if the higher education institutions would create or make their curricular 
offerings meet the trends of the economy, to make it relevant and responsive to the needs and demands of the labor market. Aside from the preparation and training a student may receive from the school. It is the duty of an institution of learning to provide the best education to its students.

\section{Related Studies}

According to Ballon (2007), a graduate who leaves the sanctuary of the academe desire to find the best employment out there in the job market. However, a job seeker's desire for the best job is hampered by lack of basic skills relevant to the job, lack of experience, poor communication and social skills and among others. Competencies learned in college, mode of job search and career-choice related factors can be considered as predictors of employability of graduates. Age, civil status, region of origin, and educational attainment are graduate-related factors that predict graduate employability. Competencies in human relations, communications and information technology serve as advantages to young graduates when looking for employment. Graduates who are recommended by someone and with strong passion for the profession immediately find employment.

In the study of Negro (2008), she revealed that out of 158 respondents, only 67 were employed. Twenty-two were permanent employees, and the rest were temporary or contractual employees. Moreover, it was revealed that employed respondents got their jobs as walk-in applicants while others were recommended by prominent people or had political connections. Furthermore, it shows that the skills relevant to their present occupation as PNP members and credit investigators were investigation, communication and problem-solving skills. And the main reason for unemployment were: lack of professional eligibility, no job opening in their field of specialization, lack of political connections, and inadequate communication skills.

On the other hand, Carale revealed in one study that the graduates have poor or inadequate training particularly in the preparation of plan of arrest, search and seizure procedures, law enforcement and crisis management intervention, the art of self-defense and in communication skills (2006).

Ibutnande (2009) reported that more than one half of the skills and competencies of the respondents who got into police work did not match with the designated positions.

In the study of Negro and Amparado (2017), they traced the graduates of UCLM, Philippines from 1997 to 2010. Specifically, it ascertained the following: profile of the respondents; reasons for taking the course; employment status of the graduates; status of the employed; strategy used to find the first job; reasons for not being employed; number of graduates who were able to land in a job relevant to the curriculum they had in college; and academic competencies learned in college which were useful on the job. It also determined the relationship between the profile of the graduates and their employment status. 
Utilizing purposive sampling, this descriptive-correlational design study utilized 281 graduates of the University of Cebu Lapu-Lapu and Mandaue from 1997 to 2010. The study showed that most of the respondents were single, female, residents of the city and from Region 7. Most have not taken any professional examination. The top reasons for taking the program was the prospect for immediate employment. Majority of the graduates were employed. Those who were employed belonged to the rank and file position in their first job and current job. They were receiving 5,000 to 10,000 Philippine pesos as monthly income. Most belonged to the education sector and working in the city. They landed on their first job through recommendations.

The top reason for accepting and staying on the first job was the pay and fringe benefits. The top reason for not being employed and never employed was the absence of a job opportunity. Most of the graduates claimed that they were able to land in a job that was relevant to the course that they took in college. The top three competencies learned in school which were useful on the job were communication skills, human relation skills and information technology skills. There was a significant relationship between the profile of the respondents in the aspect of region of origin and their employment status. In conclusion, graduates were employable. The employability of UCLM graduates was influenced by their region of origin.

\section{Objectives}

This study determined the employment status of the licensed graduates of Criminology in UCLM, Mandaue City, Cebu, Philippines. This study provided timely feedback to the university on the employment status of their graduates so that changes in the curriculum may be implemented for the success of future graduates.

\section{Methodology}

This study determined the employment status of Criminology graduates of UCLM from 2008 to 2012. Findings of the study served as basis for an employability-focused student development program. Specifically, the study ascertained the profile of the respondents in terms of age, gender, civil status, place of birth, present address, post-graduate studies and eligibilities passed. It also determined the employability skills of the respondents in terms of technical, interpersonal and conceptual/workplace skills.

The study utilized the descriptive design and used a researcher-made questionnaire. The survey was conducted at the College of Criminology in 2014. The researchers also visited offices and the residence of the respondents in Cebu City, Mandaue City, Lapu-Lapu City and some provinces in Region 7, Philippines. There were 86 respondents who joined the survey. Table 1 shows the data in frequencies and simple percentage. 
Table 1. Distribution of Respondents

\begin{tabular}{|l|c|c|c|}
\hline Year & $\mathbf{N}$ & $\mathbf{N}$ & \% \\
\hline 2008 & 52 & 20 & 23 \\
\hline 2009 & 54 & 18 & 21 \\
\hline 2010 & 65 & 19 & 22 \\
\hline 2011 & 43 & 17 & 20 \\
\hline 2012 & 48 & 12 & 14 \\
\hline Total & 262 & 86 & 100 \\
\hline
\end{tabular}

\section{Results and Discussion}

Profile in terms of age, gender, civil status, place of birth, present address, examination passed, and post graduate studies are presented in Table 2 . The study showed that majority of the respondents were $24-25$ years old (27\%), male (81\%) and single (69\%). Their birth place is Cebu Province (28\%) and presently residing in Lapu-Lapu City, Cebu (51\%). Most have passed the Criminology Licensure Examination (85\%) but has not taken any units in the master's program (96\%).

Table 2. Profile of the respondents

\begin{tabular}{|l|c|c|}
\hline Age & Frequency & \% \\
\hline $22-23$ & 15 & 18 \\
\hline $24-25$ & 23 & 27 \\
\hline $26-27$ & 20 & 23 \\
\hline $28-29$ & 20 & 9 \\
\hline 30 and above & 8 & 81 \\
\hline Gender & 70 & 19 \\
\hline Male & 16 & 69 \\
\hline Female & & 31 \\
\hline Civil status & 59 & \\
\hline Single & 27 & 8 \\
\hline Married & & 14 \\
\hline Place of birth & 7 & 28 \\
\hline Bohol & 12 & 26 \\
\hline Cebu City & 24 & 2 \\
\hline Cebu Province & 22 & 1 \\
\hline Lapu-Lapu City & 2 & \\
\hline Mandaue City & 1 & \\
\hline Negros Oriental & & \\
\hline
\end{tabular}




\begin{tabular}{|l|c|c|}
\hline Outside Region 7 & 18 & 21 \\
\hline Present address & 3 & 4 \\
\hline Bohol & 3 & 4 \\
\hline Cebu City & 19 & 22 \\
\hline Cebu Province & 44 & 51 \\
\hline Lapu-Lapu City & 15 & 17 \\
\hline Mandaue City & 2 & 2 \\
\hline Outside Region 7 & & 85 \\
\hline Eligibility & 73 & 15 \\
\hline Passed the Criminology licensure exam & 13 & \\
\hline None & & 96 \\
\hline Post graduate studies & 22 & 2 \\
\hline No master's units & 2 & 2 \\
\hline With master's units & 2 & \\
\hline Master's degree holder & & \\
\hline
\end{tabular}

Table 3 revealed that most of the respondents were employed (93\%), with regular employment status (64\%) and holding a police officer position (65\%). But it also showed that some respondents were not employed in a law enforcement agency or government office. It was noted that some graduates served as office staff. This implies that the respondents were employable either in the government or private sector.

\section{Table 3. Present employment status and occupation}

\begin{tabular}{|l|c|c|}
\hline Employment & F & \% \\
\hline Employed & 80 & 93 \\
\hline Not employed & 6 & 7 \\
\hline Present employment status & & 64 \\
\hline Permanent/regular & 51 & 36 \\
\hline Temporary/casual & 29 & 65 \\
\hline Present occupation & 52 & 3 \\
\hline Police officer & 2 & 1 \\
\hline Jail officer & 1 & 4 \\
\hline Port police & 3 & 1 \\
\hline Security guard & 1 & 9 \\
\hline Security officer & 7 & 1 \\
\hline House detective & 1 & 1 \\
\hline Civilian investigator & 1 & \\
\hline Criminology instructor & & \\
\hline
\end{tabular}


Majority of the respondents have spent less than a year before landing in a job (43\%). Respondents also confirmed that the job was relevant to the program (85\%). This implies that the respondents have acquired the necessary eligibility for immediate employment.

Table 4. Period of time spent before landing a job and relevance of the program to the present job of the respondents

\begin{tabular}{|l|c|c|}
\hline Period of time in years & F & \% \\
\hline Less than 1 year & 29 & 43 \\
\hline More than 1 year to 2 years & 16 & 24 \\
\hline More than 2 years to 3 years & 4 & 6 \\
\hline More than 3 years to 4 years & 1 & 1 \\
\hline More than 4 years to 5 years & 1 & 1 \\
\hline Not specified & 17 & 25 \\
\hline Relevance of the job to the program & & \\
\hline Relevant & 68 & 85 \\
\hline Not relevant & 12 & 15 \\
\hline
\end{tabular}

For those who were unemployed, majority of the respondents' reason was family concern (66\%) but most did not disclose the agency where they were not accepted (50\%) and the reason for failing the job application (83\%).

Table 5. Reason for unemployment, law enforcement agency where they applied and reasons for failing in the application

\begin{tabular}{|l|c|c|}
\hline Reason for unemployment & F & \% \\
\hline Health-related & 1 & 17 \\
\hline Family concern & 4 & 66 \\
\hline Not specified & 1 & 17 \\
\hline Law enforcement agency where they applied & & \\
\hline Philippine National Police & 2 & 33 \\
\hline Security agencies & 1 & 17 \\
\hline Not specified & 3 & 50 \\
\hline Reason for failing in the application & & \\
\hline Medical and dental reason & 1 & 17 \\
\hline Not specified & 5 & 83 \\
\hline
\end{tabular}


Table 6 reveals the employment skills of the respondents in terms of technical skills. Majority are efficient in disassembling and assembling firearms (56\%). They were also knowledgeable in collecting, preservation and handling of evidence (55\%). Found lowest was on being well versed in the formulation of questions in relation to conducting polygraph examination. This was expected because most of the criminologists were not given opportunities to land a job as experts on on criminalistics particularly on polygraphy as well as in investigation. This is true even for those who were employed in the Philippine National Police.

Table 6. Employment skills in terms of technical skills (multiple response)

\begin{tabular}{|l|c|c|}
\hline Technical skills & F & $\%$ \\
\hline $\begin{array}{l}\text { 1. Knowledgeable on the proper preservation of } \\
\text { latent prints. }\end{array}$ & 41 & 48 \\
\hline $\begin{array}{l}\text { 2. Knowledgeable on collecting, marking, } \\
\text { preservation and handling of evidence. }\end{array}$ & 47 & 55 \\
\hline $\begin{array}{l}\text { 3. Efficient in disassembling and assembling } \\
\text { firearms. }\end{array}$ & 48 & 56 \\
\hline $\begin{array}{l}\text { 4. Able to present and report pieces of evidence } \\
\text { during court proceedings. }\end{array}$ & 23 & 27 \\
\hline $\begin{array}{l}\text { 5. Can identify indications of genuineness and } \\
\text { falsification of a document. }\end{array}$ & 23 & 27 \\
\hline $\begin{array}{l}\text { 6. Knowledgeable on the interrogation } \\
\text { technique as applied to polygraphy. }\end{array}$ & 25 & 29 \\
\hline 7. Well versed on formulating questions. & 16 & 19 \\
\hline $\begin{array}{l}\text { 8. Abreast on gathering information } \\
\text { systematically to establish facts and principles. }\end{array}$ & 30 & 35 \\
\hline 9. Efficient in problem solving. & 23 & 27 \\
\hline
\end{tabular}

In table 7 , majority of the respondents said that they are flexible, and can adapt successfully to changing situation and environment (66\%). As police officers, they must be flexible since they have no assurance of the place of assignment. Majority of the respondents said that they are not efficient and proficient in verbal and written communication skills which has the lowest result (39\% and 37\%, respectively). 
Table 7. Employment skills in terms of interpersonal skills (multiple response)

\begin{tabular}{|l|c|c|}
\hline Interpersonal skills & F & $\%$ \\
\hline $\begin{array}{l}\text { 1. Efficient in verbal communication and able to } \\
\text { express ideas clearly and confidently in speech. }\end{array}$ & 33 & 39 \\
\hline $\begin{array}{l}\text { 2. Proficient in written communication and able } \\
\text { to express yourself in writing. }\end{array}$ & 32 & 37 \\
\hline $\begin{array}{l}\text { 3. Flexibility; can adapt successfully to } \\
\text { changing situations and environment. }\end{array}$ & 66 & 77 \\
\hline $\begin{array}{l}\text { 4. Negotiating and Persuading; you are able to } \\
\text { influence and convince others to discuss and } \\
\text { reach agreement. }\end{array}$ & 44 & 51 \\
\hline $\begin{array}{l}\text { 5. Leadership; adheres to standards and } \\
\text { procedures, maintains confidentiality and } \\
\text { questions inappropriate behaviour. }\end{array}$ & 47 & 55 \\
\hline $\begin{array}{l}\text { 6. Integrity; adheres to standards and } \\
\text { procedures, maintains confidentiality and } \\
\text { questions inappropriate behaviour. }\end{array}$ & 51 & 60 \\
\hline
\end{tabular}

In the aspect of workplace skills, majority of the respondents said that they are good in teamwork where they can work confidently within a group (83\%). The respondents claimed they cannot work independently and are not able to decide what steps are needed to achieve particular goals and implement these goals.

Table 8. Employment skills of the respondents in the aspect of workplace skills (multiple response)

\begin{tabular}{|l|c|c|}
\hline Workplace skills & F & $\%$ \\
\hline $\begin{array}{l}\text { 1. Teamwork; can work confidently within a } \\
\text { group. }\end{array}$ & 71 & 83 \\
\hline $\begin{array}{l}\text { 2. Drive; determined to get things done, make } \\
\text { things happen and constantly looking for better } \\
\text { ways of doing things. }\end{array}$ & 43 & 50 \\
\hline $\begin{array}{l}\text { 3. Personal impact/confidence; presents a } \\
\text { strong, professional, positive image to others } \\
\text { which inspires confidence and commands } \\
\text { respect. }\end{array}$ & 47 & 55 \\
\hline $\begin{array}{l}\text { 4. Stress tolerance; maintains effective } \\
\text { performance under pressure. }\end{array}$ & 40 & 47 \\
\hline $\begin{array}{l}\text { 5. Independence; accepts responsibility for } \\
\text { view. }\end{array}$ & 35 & 41 \\
\hline
\end{tabular}




\begin{tabular}{|l|c|c|}
\hline $\begin{array}{l}\text { 6. Action planning; able to decide what steps } \\
\text { are needed to achieve particular goals and } \\
\text { implement these. }\end{array}$ & 37 & 43 \\
\hline $\begin{array}{l}\text { 7. Decision-making; determines the best course } \\
\text { of action, evaluate options based on logic and } \\
\text { facts and presents solutions. }\end{array}$ & 54 & 63 \\
\hline $\begin{array}{l}\text { 8. Interpersonal sensitivity; recognizes and } \\
\text { respects different perspective; open to ideas and } \\
\text { views of others. }\end{array}$ & 48 & 56 \\
\hline
\end{tabular}

\section{Conclusion}

Criminology graduates are usually confronted with the lack of interpersonal communications. To help the students in strengthening their employability and meaningful working experience, they need to undergo adequate preparation focusing on employability while they are in their undergraduate years. The researchers recommended the establishment of a webbased graduate tracer in order to have constant updates of the graduates' status and provide an avenue for employment opportunities for the unemployed. The university shall establish linkages to the different industries that may help provide employment opportunities for the graduates. 


\section{Literature Cited}

Adler, F. et. al. (2010). Criminology. $2^{\text {nd }}$ edition. USA: Mc Graw-Hill Inc.

Ballon, A. E. (2007). Predictors of Employability of the Graduates of Technological Institute of the Philippines Quezon City. TIP Research Journal Quezon City, 4 (1), 1-1.

Brown, S. \& Lent, R. (2005). Career development and counseling.

Putting theory and research to work. New Jersey, USA: Wiley \& Sons Inc.

Capuzzi, D. \& Stauffer, M. (2012). Career counseling: Foundation, perspective and applications. New York: Taylor \& Francis Group.

Carale, A.J. (2006). A tracer study of Criminology graduates of Colegio de Santa de Alejandria from 1998-2004. Cebu City, Philippines: University of Cebu.

Eliason, G. \& Patrick, J. (2008). Career development in the school. USA: Information Age Publishing Inc.

Florendo, A.M. (2012). Fundamentals of criminal investigation. Quezon City: Wisemans Book Trading.

Hayes, J. (2002). Interpersonal skills at work. Psychology Press.

Ibutnande, D. (2009). Employability level of Criminology graduates of Northern Visayas Colleges, Kalibo, Aklan. Cebu City: University of Cebu.

Krumboltz, J. D. (2009). The happenstance learning theory. Journal of Career Assessment, 17 (2), 135-154.

Licudine, G. N. (2012). Graduate tracer study of batch 2010 of Philippine College of Criminology, Bachelor of Science in Criminology. Philippines: Philippine College of Criminology

Marini, I. (2009). The professional desk conference. Springer Publications.

Mendez, M. C. (2012). Gov't needs to redirect skills dev't program to address employment Escudero says. Retrieved from http://www.philstar.com 
Module 6. Tertiary education and national development. Retrieved on August 14, 2013. Retrieved from http://www.openuni-clsu.edu.ph/openfiles/modules/ed811/Module6.doc

More, H.W. \& Miller, L.S. (2011). Effective police supervision. $6^{\text {th }}$ edition. Andersons Publication.

Negro, E. O. (2008). A tracer study on Criminology graduates of Sto. Nino Ormoc from SY 2003 to 2007: Measures to enhance their employability. Cebu City, Philippines: University of Cebu.

Negro, E.O. \& Amparado, M. A. P. (2017). The employability of the University of Cebu Lapu-Lapu and Mandaue graduates from 1997 to 2010. IAMURE International Journal of Social Sciences, 19(1), 102-114.

Negro, E.O. \& Amparado, M. A. P. (2017). The employability of the University of Cebu Lapu-Lapu and Mandaue graduates from 1997 to 2010. IAMURE, 88.

Robbins, S. P. \& Coulter, M. (2001). Management. $6^{\text {th }}$ edition. Philippines: Pearson Education Asia Pte. Ltd.

Robinson, J. P. (2000). What are employability skills. The workplace, 1(3), 1-3.

The Philippine Star (2013 February 14). Graduates' employability:

Basis for success at MCL.

Vito, G.F. et. al. (2007). Criminology, theory, research and policy. $2^{\text {nd }}$ edition. Sudbury, Massachusetts: Jones \& Bartlett Publisher Inc.

Why is employability important? Retrieved on September 1, 2013. Retrieved from http://www.employability.ed.ac.uk/Why/

Recommended citation: Ruiz, D. F. A., Pioquinto, P. V. \& Amparado, M. A. P. (2020). Employment Status of Criminology Graduates. Cebu Journal of Criminal Justice, 1(1), 86-100. 